$1-22-2018$

\title{
The diversity of the modern in amazonia
}

\author{
Suzanne Oakdale
}

Marnie Watson

Missouri State University

Follow this and additional works at: https://bearworks.missouristate.edu/articles-chpa

\section{Recommended Citation}

Oakdale, Suzanne, and Marnie Watson. "The diversity of the modern in Amazonia." Journal of Anthropological Research 74, no. 1 (2018): 1-9.

This article or document was made available through BearWorks, the institutional repository of Missouri State University. The work contained in it may be protected by copyright and require permission of the copyright holder for reuse or redistribution.

For more information, please contact BearWorks@library.missouristate.edu. 


\title{
The Diversity of the Modern in Amazonia
}

\author{
SUZANNE OAKDALE, Department of Anthropology, University of New Mexico, \\ Albuquerque, NM 87131,USA. Email: soakdale@unm.edu \\ MARNIE WATS ON, Department of Sociology and Anthropology, Missouri State University
}

Key words: Amazonia, Brazil, Modernity

As several scholars have observed, modernity is a mode of understanding time and space, a chronotope in the Bakhtinian sense. The modern understanding of progress has made the present radically discontinuous with the past and the future empty or open to possibility in ways that they had not been previously (Koselleck 1985). In tandem with the growth of global managerial connections, a range of locales became spaces of "'the primitive Other' against which European Enlightenment and colonialism were elevated and justified" (Knauft 2002:6). The construction of these locales as non-modern is an artifact of modernity itself, not an absence, in fact, of the modern (Trouillot 2002). Social life in modern parts of the world came to be understood as "disembedded," or pulled away from local contexts and expanded across space and time (Giddens 1990). Non-modern locales, by contrast, were seen as repositories of a still locally situated social life. The inhabitants of a modern type of space-time came to be characterized by interiority, self-monitoring, and individualism, and those of the non-modern, by a relative lack of these features (Foucault 1979, 1990; Knauft 2002; Taylor 1989).

Despite the fact that, as Stephen Nugent observes, the Amazon can be considered "nothing but modern," having been integrated into the world system for half of a millennium, Amazonia is viewed as one of the most "non-modern" regions of the world, one of the starkest contrasts to the modern that is still in existence (2000:233; Nugent and Harris 2004). In nation-building, literature, the sciences, and the global imagination more generally, it has been considered a repository for the primitive, the traditional, the backward, the raw, the natural, and the past. Whether "green hell" or "the lungs of the planet" or "a land out of time," the Amazon region is seen as a space of nature rather than culture, frozen in time in what McClintock (1995) dubs "anachronistic space," instead of being involved in a forward march of progress (see also Campbell 2015: Nugent 2000). Simultaneously, Amazonia is considered a place of untapped potential, waiting to yield its riches if only the proper technology, scientific technique,

Submitted June 16, 2017; accepted June 17, 2017; published online January 22, 2018. Journal of Anthropological Research (Spring 2018). (C) 2018 by The University of New Mexico. All rights reserved. 0091-7710/2017/7401-0001\$10.00 
or development project were implemented. Inhabitants of the Amazon have been viewed as unable to manage the region on their own, because of either innate biological shortcomings, social and cultural deficiencies, or environmentally induced indolence, and rarely have they been consulted or considered as equal partners in modernizing and developmental schemes. Discourses that view modernity as springing from fundamentally European roots have placed Amazonia and Amazonians on the lowest evolutionary rung, and even urban inhabitants of the region are still viewed as what Chatterjee (1997) terms "consumers," rather than "producers," of modernity. At the same time, Amazonia is idealized as a locale of authenticity and viewed nostalgically as a place where people live meaningful simple lives, all part of the fetishization of the past that is a symptom of capitalism itself (Chakrabarty 2000; Ferguson 2010).

The articles in this special issue are part of the growing body of scholarship which looks beyond an exclusive focus on the peoples usually considered to be representative of this area, namely indigenous Amazonians, to the rich range of societies inhabiting this region (Campbell 2015; Chibnik 1991, 1994; Harris 1998, 2000; Despres 1991; Nugent 1981, 1993, 1995, 1999; Nugent and Harris 2004; Pace 1998; Raffles 2002; Slater 1994, 2002; Wagley 1976). The four articles presented here all focus on Amazonian Brazil to examine how a range of peoples (urban, rural, migrant, immigrant, indigenous, or mixed race, etc.) have engaged with discourses and practices of modernity and non-modernity in high-profile, relatively spectacular or monumental events and processes that have unfolded in this region (Figure 1). As such, they form a complement to research that centers on the quotidian lives of Amazonians being carried on behind the overblown rhetoric about Amazonia (see Despres 1991; Nugent and Harris 2004; Slater 1994, 2002). The articles here all show examples of how the rhetoric and stereotypes about Amazonia and modernity circulating at national and international levels have been engaged by locals, how they have been assumed, contested, or reworked. We shed light on this process at four historical moments ranging from the late nineteenth century to the present. We begin in the city of Manaus, examining the way in which latenineteenth-century postcard production assertively represented this city as a modern "technometropolis," on par with European cities. Next, we turn to one of Henry Ford's projects to build a town in the model of the "village industry" on the Tapajós River in the early twentieth century. The following article examines a project to establish Brazilian aviation networks across the interior during the mid-twentieth-century state-sponsored "March to the West." The final article focuses on a highly mediated and commodified folklore festival produced by the working class of contemporary Manaus, home to a $10,000-\mathrm{km}$ tax-free assembly and production zone. In these examples, peoples' engagement with the spectacular rhetoric of modernity and its alter-image, the traditional, does not necessarily lead to less authentic, or less directly lived, experiences (contrary to Debord 1983), but rather to a range of emotional responses-the aspirational and optimistic celebration of Manaus as a modern world city (Chernela and Pereira), the development of a heartfelt engagement with the "nature" constructed in these modern projects' wake (Killick), the long-term partnerships between individuals 


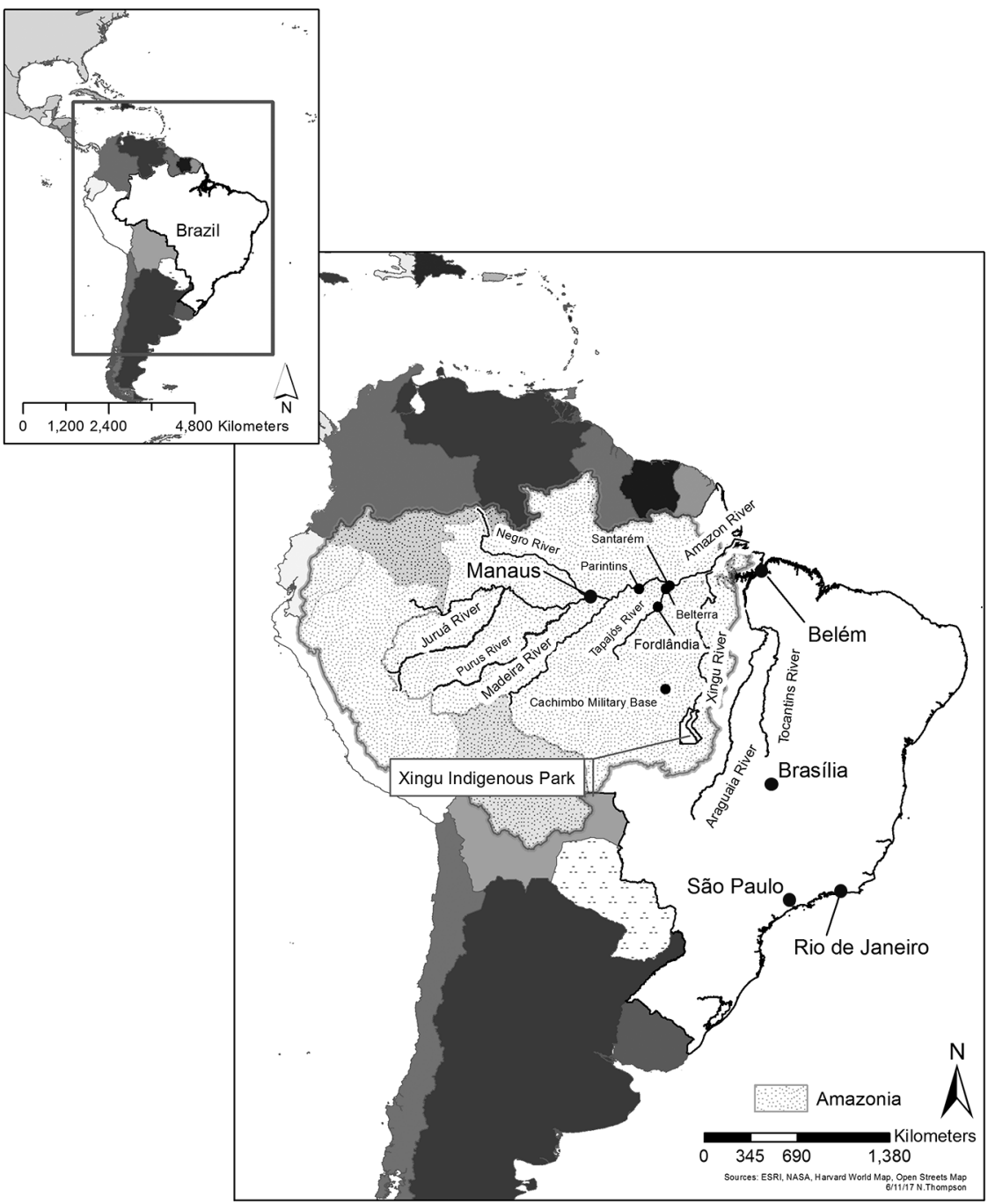

Figure 1. The Brazilian Amazon, showing locations discussed in the special issue

from different social worlds (Oakdale), and deeply satisfying identifications with past ways of life (Watson).

While modernity has moved into the domain of the "sublime," a term often evoked more than defined (Kelly 2002), we understand it here as an attitude or mode of experience which encompasses what has been termed "modernization," or its political and economic effects, as well as "modernism," the ideas and values animating art and other aesthetic sensibilities (Burman 1988; see also Nugent 2000). As Nugent observes, the Brazilian Amazon has usually been seen as a locus only for the study of modernization, given that it has been the setting of significant, large-scale economic projects (Nugent 
and Harris 2004:5). The authors in this issue examine how claims to modernity (including both modernization and modernism) and its alter image, "the traditional," have been made in the Brazilian Amazon, and how modernity has been evoked and used at particular historical moments by Amazonians themselves (see Cooper 2005).

The eras covered here are clearly not exhaustive, but they are key moments when assertions of modernity (or tradition) have become high-profile spectacles. These moments include firstly, with Chernela and Pereira's (2018) article on the postcard representation of Manaus's spectacular architecture, the Amazon of the rubber era (early 1800 s to 1914), characterized by a system of extraction, debt, and trade that linked rubber tappers in the Amazon (migrants as well as locals) to trading houses in Manaus and Belem as well as more distantly to foreign industrialists. This socioeconomic system atrophied when, in the early twentieth century, rubber prices fell precipitously as Asian rubber entered the market (Dean 1987; Weinstein 1983). During his time in office at the height of the rubber era, Eduardo Gonçalves Ribeiro, governor of Amazonas from 1892 to 1896 , embarked on a program of beautification and modernization that would transform Manaus into the "Paris of the Tropics," with electric lights, the famous Opera House, a British-designed floating wharf, paved roads, schools, hospitals, bridges, and a cathedral (Despres 1991; Mesquita 1999).

With Killick's article (2018) on Henry Ford's second Amazonian company town built in 1934, Belterra, as well as Oakdale's discussion (2018) of the Roncador-Xingu Expedition, initiated in 1943 as a part of "Brazil's March to the West," we turn to the next historical era of concern. This is one in which large-scale projects to develop the Amazon were also high-profile, newsworthy events. Both projects involved harvesting Amazonian resources - for Ford, rubber, and for the March to the West, a variety of minerals. They were also concerned, however, with populating the area with more ideal sorts of societies. For Ford, this meant communities based on a Midwestern American pastoral and sanitary ideal (Grandin 2009) and for the March to the West, it meant nonindigenous agriculturalists from eastern Brazil (Garfield 2001). Both projects were also of interest to the press; for example, by establishing plantations and towns in the Amazon, Ford was involved in a "titanic fight between nature and modern man," according to one German newspaper (Grandin 2009:4). Similarly the March to the West appeared frequently in Brazilian media, such as the illustrated weekly magazine O Cruzeiro and the state-funded Cultura Politica (Andrade 2010; Costa and Burgi 2012). President Getúlio Vargas, who initiated the March to the West, in fact began what was later called the "discourse of the Amazon River" in government propaganda of this era (Andrade 2010).

Killick's article (2018) also moves to the present, with his discussion of Belterra today, as does Watson's (2018) article on contemporary Manaus. Both the presentday town of Belterra and the free trade zone of Manaus were shaped by government modernization projects in the Amazon. While Manaus languished after the collapse of the Brazilian rubber industry, it remained a strategic location for governmental projects seeking to encourage settlement in the Amazon, in part to protect the vulnerable 
forest border. The military regime's (1964-1985) slogan was "integrar para näo entregar," or "integrate so that others may not appropriate" (Nugent 1999). The Zona Franca de Manaus, a tax-free manufacturing and assembly district, was established in 1967 as a strategy to draw industry and workers to the Amazon. The Transamazon Highway was financed in 1970 and the National Integration Plan drew small farmers to cultivate along its course, which stretched from the eastern states of Maranhão and Pará, passing very close to the town of Belterra, to the western state of Acre (Schmink and Wood 1992). By the mid 1970s capital-intensive investments were favored again. Large investors, who had been given government tax and credit advantages, arrived, pushing these smaller agriculturalists out to create pastures for cattle, mines, and farms encompassing large tracts of land, causing a significant number of migrants to become landless (Schmink and Wood 1992). Many of those migrants who stayed in the Amazon moved to Manaus or small towns along the highway.

Performing or asserting modernity involves two different ways this complex of ideas (related to both modernization and modernism) can be deployed: "modernity" can be evoked in the singular or "modernities" in the plural. Modernity in the singular is understood to originate in the West-Europe, North America, and in the context of Brazil, usually in the country's more urban and industrialized south. Only after originating or touching down in urban Brazil is it carried to the Amazon. Modernity in this singular sense can be understood either as involving a liberation from backwardness and inferior, local standards or as an imperial construct that "tames and sterilizes diversity" (Cooper 2005:113). "Plural" or "vernacular modernities," in contrast, are understood as equally valid alternative versions of how to achieve progress, usually selfconsciously distinct in at least some ways from modernity in the singular (Cooper 2005).

Claims to modernity in the singular, as an import from centers of power, foreground the larger political economic networks and inequalities that have contributed to shaping Amazonia and Brazil (see Donham 2002; Knauft 2002). It has been argued that the concept of "plural modernities," which implies that each modernity is on "equal footing," in fact "smooths out what are in reality vast differences in power and wealth" (Donham 2002:241). In each of the contexts discussed here in which modernity in the singular is asserted, the wealth and technologies from elsewhere that have significantly shaped Amazonian people's lives do in fact come into view. Evan Killick's article, for example, looks at how the philosophy of industrialist Henry Ford shaped a company town, Belterra, in the rubber-rich Tapajós River area and, as a result, not only created a distinctive town structure but also had considerable influence on the construction of areas now considered, even by residents, to be examples of Amazonian nature. Janet Chernela and Ester Pereira's article about a German photographer who crafted images of the city of Manaus during the height of the rubber era in the mold of the ideal European modern city, demonstrates how technology in the hands of even a single artist, in the right time and place, can have significant impact on forging a city's image on the global stage. Suzanne Oakdale's work on the aviation projects that took 
place in midcentury Brazil opens up a context in which the Brazilian military's access to US airplanes and techniques of surveying significantly reduced indigenous control of territory. Marnie Watson's, which focuses on Manaus during its life as a free trade zone, is sensitive to how modernity in the singular is a constant idea lurking in the background, a discourse with which residents of Manaus must continually contend as they are typecast as marginal to progress, even as they work to build high-tech products.

Articles focusing on the invocation of modernity in the singular also carry on the impulse to complicate and enrich the picture of what this sort of modernity entails. As Frederick Cooper (2005) has observed, modernity even in the West is a much less integrated and coherent package than is often assumed. Emphasizing what is generically seen to be "modern" causes one to miss the importance of other aspects (Cooper 2005:126). As Marshall Burman writes, commenting on Marx's characterization of modern life, this state is "radically contradictory at its base," it is "a world where everything is pregnant with its contrary" (1988:22). Donald Donham, emphasizing the heterogeneous nature of "modernity," likewise observes that the French Revolution inspired missionary societies which attempted to bring history to a close as well as the idea more frequently associated with modernity, that the future is an empty, unknowable space (2002:246). For him, modernity produces "refractions and refusals," what he calls "anti-modernisms." Killick's article finds one such antimodernism in one of the most unlikely places: the works of Henry Ford. In Ford's writings and plans for a company town in the Amazon, Killick finds not a separation between modernity and ecology, but rather an interest in attaining the pastoral ideal while also pursuing industrial production. Ford's ideas, according to Killick, show "a much more hybrid and unseparated vision of the relation between nature and human actions than is usually associated with the term [modernity]." Similarly, Oakdale's article identifies an openness to "multinaturalism," or an appreciation of the subjectivity of nonhuman entities, seen to be characteristic of Amazonian cosmologies (Viveiros de Castro 1998), in the diaries of the leaders of Brazil's midcentury March to the West, a quintessentially modernizing project to explore and colonize the interior.

Some of the following articles also focus on how plural modernities (Brazilian, Amazonian, indigenous) have been claimed as this discourse on modernity in the singular was adopted, rejected, or reshaped in Brazilian contexts. Oakdale explores the midcentury state commentary on how the interior would be incorporated into the "progress" of the rest of the nation by merging the distinctive, old-fashioned Brazilian elements (the tried-and-true home remedies, traditional foods, and travel by canoe) with the modern elements (imported medicine, canned goods, and air travel). The mestiço or hybrid modernity idealized in this state project is self-consciously distinct from European or North American modernity.

Chernela and Pereira's article as well as Watson's focus on the tensions between high-profile images and the lived reality of residents of Manaus with respect to modernity in the singular and plural. Chernela and Pereira reveal how postcards of the rubber era were produced in a public relations effort to prove the city was indeed the famed 
"Paris of the Tropics." These images deliberately chose to depict an idealized reality from an angle that concealed the daily struggles of those who were excluded from participation in this modernizing project. Watson's article takes up where the former leaves off, after the collapse of the rubber economy and the implantation of the Zona Franca de Manaus that now encompasses the city. In the twenty-first century, people from Manaus remain unable to convince their compatriots of the city's modernity, as national media images generally erase all signs of urbanization or technology from depictions of Amazonia. Watson demonstrates how the creators and celebrants of the boibumbá festival knowingly play with nostalgic images of pre-modernity as they construct a modern identity rooted in local history but intended for a global audience.

Taken as a whole these articles, following the work of others (see above), suggest that the "modern" is a complex category, especially in the Brazilian Amazon. The contexts they explore show how Amazonians themselves have engaged with some of the more spectacular assertions of modernity and non-modernity over the past one hundred and fifty years. They focus on how a range of people, including immigrants, migrants, descendants of migrants, indigenous individuals, expedition leaders who took on the interior as a second home, as well as urban workers, have asserted in different ways that they are both modern and non-modern, thereby deploying, reacting to, and reshaping the terms in general circulation with respect to the Amazon and modernity. While the complexity of the "modern" has been recently explored in the social sciences, including notably by Bruno Latour (1993), "modernity" and those who inhabit it, "the moderns," in caricature, seem to have slipped back into some ontologically oriented Amazonian anthropology. "The modern" often provides a neat contrast to the indigenous groups ("the Amerindians") that have long been taken to represent the Amazon (Nugent 1993) (see Killick 2018). Offering historically situated examples with which to think through some of the less tidy ways that people have made claims about modernity, modernities, and anti-modernity in Amazonia, the articles that follow show how those who live there (including indigenous people) have themselves been in dialogue with these terms for a very long time.

\section{NOTE}

We would like to thank all of the participants in the session on Modernity in Amazonia at the annual meeting of the American Anthropological Association held in Washington DC on December 7, 2014, especially Beth Conklin, for her insightful comments as discussant, as well as Sean Mitchell and Jeremy Campbell for the papers they each presented in the session. We also thank the audience members for the lively discussion afterward. This introduction has benefited greatly from the comments of the anonymous reviewers as well as from the editor, Lawrence Straus.

\section{REFERENCES CITED}

Andrade, Romulo 2010. "Conquistar a terra, dominar a água, sujeitar a floresta": Getúlio Vargas e a revista "Cultura Política" redescobrem a Amazônia (1940-1941). Boletim do Museu 
Paraense Emilio Goeldi. Ciências Humans 5(2). Accessed on June 5, 2017 at http://www . scielo.br/scielo.php?script $=$ sci_arttext\&pid $=$ S1981-81222010000200015

Burman, Marshall. 1988. All that is solid melts into air: The experience of modernity. London: Penguin Classics. (Originally published in 1982)

Campbell, Jeremy. 2015. Conjuring property: Speculation and environmental futures in the Brazilian Amazon. Seattle: University of Washington Press.

Chakrabarty, Dipesh. 2000. Provincializing Europe. Princeton, NJ: Princeton University Press.

Chatterjee, Partha. 1997. Our modernity. Rotterdam/Dakar: South-South Exchange Programme for Research on the History of Development (SEPHIS) and the Council for the Development of Social Science Research in Africa (CODESRIA).

Chernela, Janet, and Ester Pereira. 2018. An end to difference: Imagining Amazonian modernity at the dawn of the twentieth century. Journal of Anthropological Research 74(1):00-00.

Chibnik, Michael. 1991. Quasi-ethnic groups in Amazonia. Ethnology 30(2):167-82.

- 1994. Risky rivers: The economics and politics of floodplain farming in Amazonia. Tucson: University of Arizona Press.

Cooper, Frederick. 2005. Colonialism in question. Berkeley: University of California Press.

Costa, Helouise, and Sergio Burgi. 2012. As origens do fotojournalismo no Brasil: Um olhar sobre O Cruzeiro 1940-1960. São Paulo: Instituto Moreira Salles.

Dean, Warren. 1987. Brazil and the struggle for rubber: A study in environmental history. Cambridge: Cambridge University Press.

Debord, Guy. 1983. Society of the spectacle, trans. Ken Knabb. London: Rebel Press.

Despres, Leo A. 1991. Manaus: Social life and work in Brazil's Free Trade Zone. Albany: University of New York Press.

Donham, Donald L. 2002. "On being modern in a capitalist world," in Critically modern: Alternatives, alterities, anthropologies. Edited by B. M. Knauft, pp. 241-57. Bloomington: Indiana University Press.

Ferguson, Jane. 2010. Another country is the past: Western cowboys, Lanna nostalgia, and bluegrass aesthetics as performed by professional musicians in Northern Thailand. American Ethnologist 37(2):227-40.

Foucault, Michel. 1979. Discipline and punish: The birth of the prison. New York: Vintage.

- 1990 [1978]. The history of sexuality, trans. R. Hurley. New York: Vintage Books.

Garfield, Seth. 2001. Indigenous struggle at the heart of Brazil. Durham, NC: Duke University Press.

Giddens, Anthony. 1990. The consequences of modernity. Stanford: Stanford University Press.

Grandin, Greg. 2009. Fordlandia: The rise and fall of Henry Ford's forgotten jungle city. New York: Metropolitan Books, Henry Holt.

Harris, Mark. 1998. The rhythm of life on the Amazon floodplain: Seasonality and sociality in a riverine village. Journal of the Royal Anthropological Institute 4(1):65-82.

- 2000. Life on the Amazon: The anthropology of a Brazilian peasant village. Oxford: Oxford University Press.

Kelly, John D. 2002. "Modernity and other traditions," in Critically modern: Alternatives, alterities, anthropologies. Edited by B. M. Knauft, pp. 258-86. Bloomington: Indiana University Press.

Killick, Evan. 2018. Rubber, Terra Preta, and soy: A study of visible and invisible Amazonian modernities. Journal of Anthropological Research 74(1):00-00. 
Knauft, Bruce. 2002. "Introduction," in Critically modern: Alternatives, alterities, anthropologies. Edited by B. M. Knauft, pp. 1-56. Bloomington: Indiana University Press.

Koselleck, Reinhart. 1985. Futures past: On the semantics of historical time. New York: Columbia University Press.

Latour, Bruno. 1993. We have never been modern (trans. by C. Porter). Cambridge, MA: Harvard University Press.

McClintock, Anne. 1995. Imperial leather: Race, gender, and sexuality in the colonial contest. New York: Routledge.

Mesquita, Otoni. 1999. Manaus: História e arquitetura (1852-1910). Manaus: Editoria Valer. Nugent, Stephen. 1981. Amazonia: Ecosystem and social system. Man n.s. 16(1):62-74.

-1993. Amazonian caboclo society: An essay on invisibility and peasant economy. Providence, RI: Berg.

- 1995. Big mouth: The Amazon speaks. San Francisco: Brown Trout Press

1999. "Verging on the marginal: Modern Amazonian peasantries," in Lilies of the field: Marginal people who live for the moment. Studies in the ethnographic imagination. Edited by S. Day, M. Stewart, and E. Papataxiarchis, pp 179-95. Boulder: Westview Press.

- 2000. "Good risk, bad risk: Reflexive modernism of Amazonia," in Risk revisited. Edited by P. Caplan, pp. 226-48. London: Pluto Press.

Nugent, Stephen, and Mark Harris. 2004. Some other Amazonians: Perspectives on modern Amazonians. London: Institute for the Study of the Americas/Brookings Institute.

Oakdale, Suzanne. 2018. Brazil's "March to the West": Memories of an indigenous shaman and other "moderns." Journal of Anthropological Research 74(1):00-00.

Pace, Richard. 1998. The struggle for Amazon town: Gurupá revisited. Boulder: Lynne Reiner. Raffles, Hugh. 2002. In Amazonia: A natural history. Princeton: Princeton University Press.

Schmink, Marianne, and Charles Wood. 1992. Contested frontiers in Amazonia. New York: Columbia University Press.

Slater, Candace. 1994. Dance of the dolphin: Transformation and disenchantment in the Amazonian imagination. Chicago: University of Chicago Press.

2002. Entangled Edens: Visions of the Amazon. Berkeley: University of California Press.

Taylor, Charles. 1989. Sources of the self: The making of modern identity. Cambridge, MA: Harvard University Press.

Trouillot, Michel-Rolph. 2002. "The otherwise modern: Caribbean lessons from the savage slot," in Critically modern: Alternatives, alterities, anthropologies. Edited by B. M. Knauft, pp. 220-40. Bloomington: Indiana University Press.

Viveiros de Castro, Eduardo. 1998. Cosmological deixis and Amerindian perspectivism. Journal of the Royal Anthropological Institute 4(3):469-88.

Wagley, Charles. 1976 [1953]. Amazon town: A study of man in the Tropics. London: Oxford University Press.

Watson, Marnie K. 2018. "It tells all of our history!" The boi-bumbá festival of Manaus. Journal of Anthropological Research 74(1):00-00.

Weinstein, Barbara. 1983. The Amazon rubber boom, 1850-1920. Stanford, CA: Stanford University. 